Historic, Archive Document

Do not assume content reflects current scientific knowledge, policies, or practices. 
2 


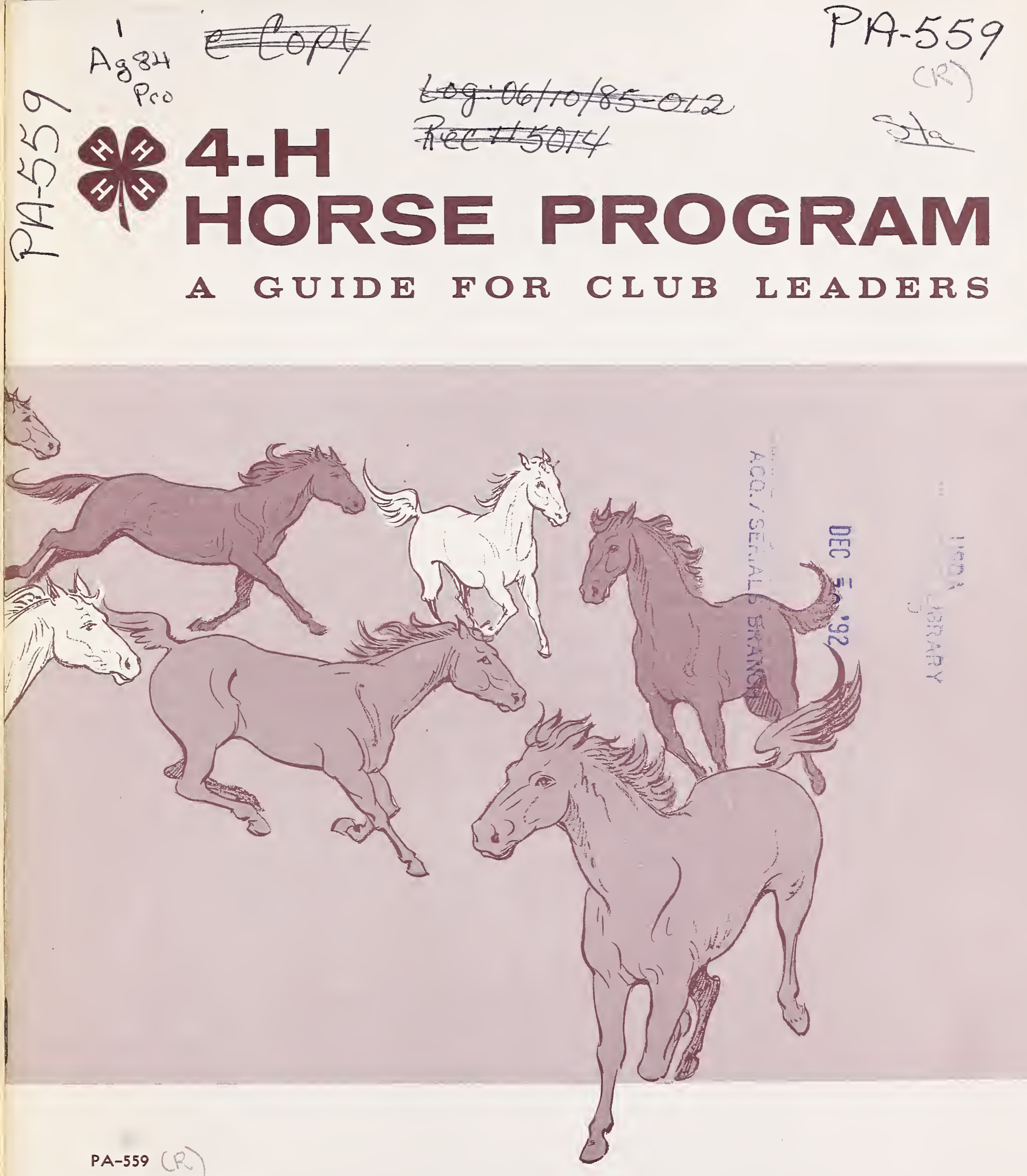

Federal Extension Service

U.S. DEPARTMENT OF AGRICULTURE

For sale by the Superintendent of Documents, U.S. Government Printing Office, Washington 25, D. C. 


\section{CONTENTS}

Objectives of the 4-H Horse Project...... . ..... 3

Your Job as a Leader.................... 5

The Challenge....................... 5

The Youth You Lead.................... 5

Requirements........................ 6

Membership....................... 6

Animals......................... 6

Supervising the Project................... 7

Selecting the Horse..................... 7

Care, Feeding, and Management.......... 7

Keeping Records....................... 8

Teaching Suggestions. . . . . . . . . . . . . . . . . . 8

Subject Matter Suggestions for Club Meetings. . 9

Demonstrations...................... 9

Showing Horses. . . . . . . . . . . . . . . . . . . . . . . 12

Rules About Wording. . . . . . . . . . . . . ... 12

Eligibility for Shows..................... 12

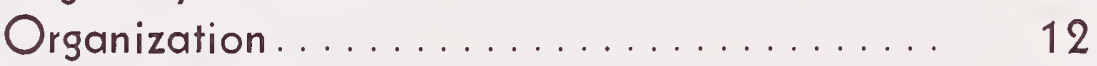

Some Horse Show Guidelines. . . . . . . . . . . . . 13

Uniform Score Cards for 4-H Classes.... . . . . . . . . 14

Fitting and Showmanship................ 14

Western Horsemanship..................... 16

Western Pleasure....................... 16

Working Stock Horse. . . . . . . . . . . . . . . . 16

English Horsemanship................... $\quad 17$

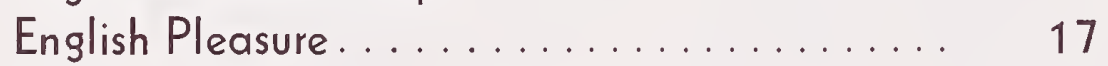

Trail.............................. 18

Clothing and Equipment Suggestions........... 18

Safety Precautions. . . . . . . . . . . . . . . . . . . . . . 18

Acknowledgments-the text for this publication resulted from the work of committees composed of:

Frank H. Baker, Extension Animal Scientist, Federal Extension Service; Charles E. Bell, Jr., Director, Division of Agricultural Science, Technology, and Management, Federal Extension Scrvice; Mylo S. Downey, Director, Division of 4-H and Youth Development, Federal Extension Service; Don C. Gaylord, Extension Animal Husbandinan, University of Connecticut, Storrs; N. A. Jacobscn, Extension Livestock Specialist, Montana State College, Bozeman; Joe B. Jolnson, Extension Animal Husbandman, Washington State University, Pullınan; Ralph Morrow', Extension Animal Husbandınan, Michigan State Univcrsity, East Lansing; Harry F. Moxley, Extension Animal Husbandman, Michigan State University, East Lansing; Harold A. Willınan, 4-H Livestock Specialist, Cornell University, Ithaca, N.Y.

Photo Credits: California, Connecticut, New York, and Pennsylvania Extension serviccs, and Washington State University. 


\section{Objectives of the 4-H Horse Project}

The 4-H Horse Project aims to help 4-H members to:

1. Develop leadership, initiative, self-reliance, sportsmanship and other desirable traits of character.

2. Experience the pride of owning a horse or pony and being responsible for its management.

3. Develop an appreciation of horseback riding as a healthy and wholesome form of recreation.

4. Learn skill in horsemanship and an understanding of the business of breeding, raising and training horses.

5. Increase knowledge of safety precautions to prevent injury to themselves, others and their mount.

6. Promote greater love for animals and a humane attitude toward them.

7. To be better prepared for citizenship responsibilities through working in groups and supporting community horse projects and activities. 


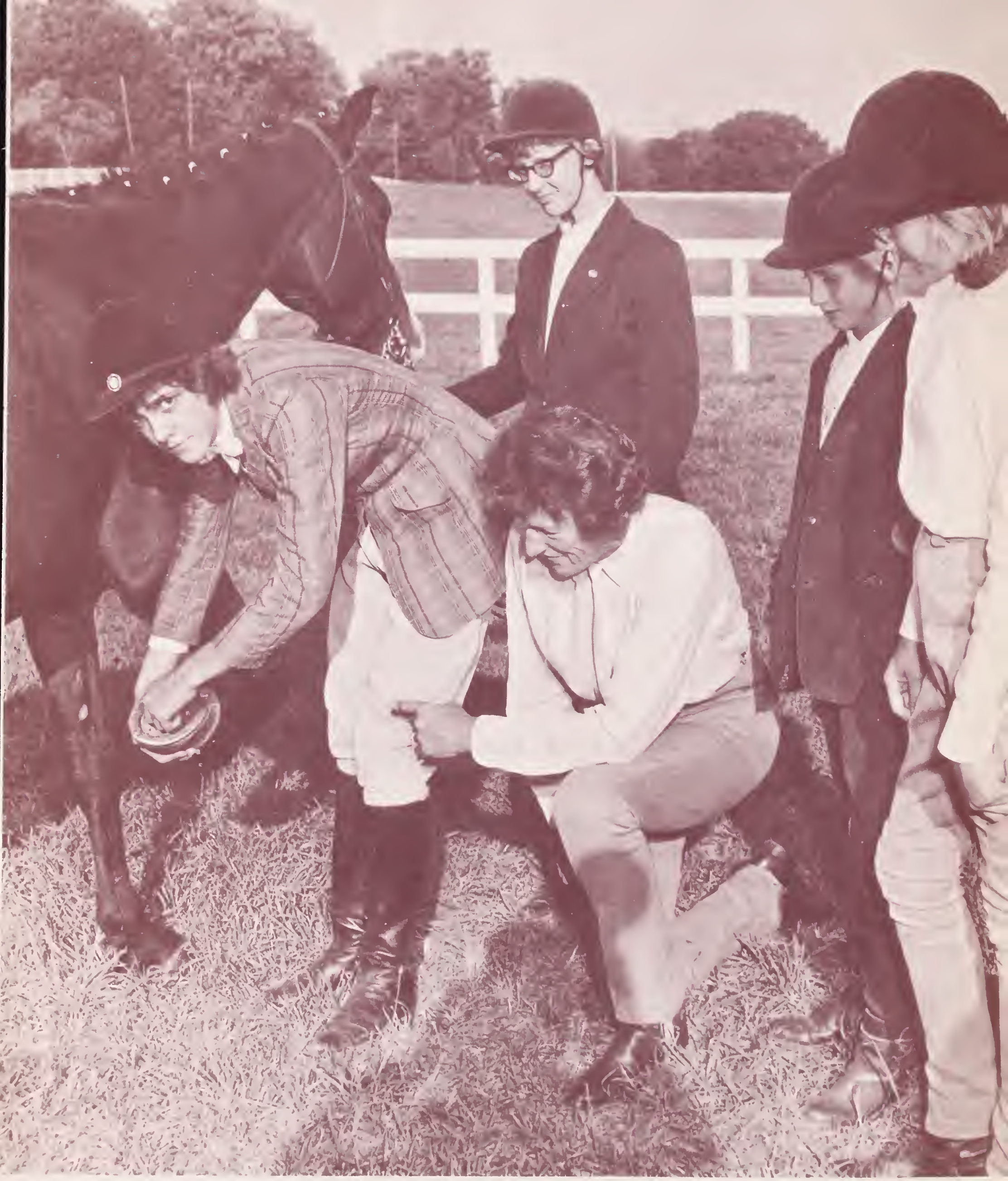

The 4-H leader is rewarded in seeing young people develop into finer adults through their project work with horses. 


\section{- 4. \\ HORSE PROGRAM \\ A GUIDE FOR CLUB LEADERS}

\section{YOUR JOB AS A LEADER}

\section{The Challenge}

Your responsibility as a local leader is both a challenge and an opportunity. Yours is a key position in the $4-\mathrm{H}$ Club program. If you enjoy working with young people and like horses, you will find the time spent working with the $4-\mathrm{H}$ horse program most rewarding. You'll find great satisfaction in watching boys. and girls develop new knowledge and skills under your guidance. The horse project gives them special learning opportunities in animal care, outdoor activities, safety first and participation in group activities.

Through your efforts, club members will learn many things that will better prepare them to assume places of leadership in their community. Your own activities will be varied as you:

- help members plan their own programs

- attend their club meetings

- supervise their training

- visit their homes to see how they are progressing

- advise them on the care of their animals

- accompany them on trail rides and to events outside the county.

You are the club member's friend who is close by when the boy or girl wants advice or help.
A successful leader is the person who has the confidence of the group; keeps ahead of them, yet seems always with them, understands their viewpoint; is tolerant, patient, and sympathetic in working with them. He recognizes work well done in such a way that young people will be encouraged to do even better; makes friendly suggestions instead of displaying authority; and provides situations that will afford them larger responsibilities as they become more experienced.

Boys and girls are prone to look upon such a person as their ideal. This places a great responsibility on the leader for setting the right personal examples. Here is your opportunity to inspire club members to emulate attitudes and ideas that make for upstanding manhood and womanhood.

You don't have to do the job without help. There are others in your community who will be glad to assist. In addition, older club members can serve as assistants and junior leaders. They can do many routine jobs.

\section{The Youth You Lead}

The broad objective of the $4-H$ horse program is to help boys and girls develop leadership, character, and effective citizenship. Each boy and girl is an individual with his own background, personality. talents, experi- 
ences, and aspirations. Why do they behave as they do? Why is one so different in behavior from another? An understanding of these differences can come from working with each individual.

As a leader, you will find that getting to really know each boy or girl will help you guide them as they gain confidence in working with a group. It will help you in adjusting their activities to fit their needs and in increasing the pleasure and satisfaction they will derive from their $4-\mathrm{H}$ Club experience.

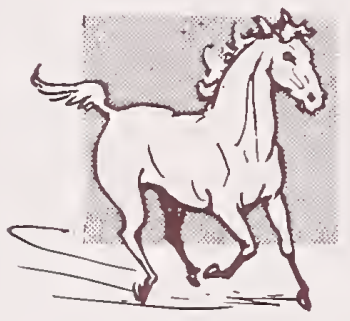

\section{REQUIREMENTS}

(Recommended in most States)

\section{MEMBERSHIP}

Boys and girls who enroll in this project should:

1. Be 10-19 years of age.

2. Attend meetings of club, participate in the programs.

3. Own or manage an animal.

4. Keep a record book provided for the project.

5. Receive a membership card proving eligibility for $4-\mathrm{H}$ Show.

\section{ANIMALS}

1. Foals, ponies and horses are suitable for this project.

2. A member owning his own horse must manage that horse 75 percent of the time. "Management" includes feeding, grooming, exercising, training, stall management and free access to the use of the horse at all times.

3. A family-owned horse may be managed by two members of a family on a 50 percent basis.

4. A non-family-owned horse must be managed at least 80 percent of the time. All horses managed on this basis must have an affidavit from the owner that the member manages the horse 80 percent or more and that the member has free access to the horse.

5. No horse that is rented by a child at any time, whether it be for riding, instruction, or showing may be used as a 4-H Iforse Project or slown in a 4-H Horse Show. 


\section{SUPERVISING THE PROJECT}

\section{Selecting the Horse}

Some members will already own a horse when they join the 4-H Club. You should be prepared to counsel with the parents and club members as to the type of horse that meets the member's need. Selecting the correct horse will add to the satisfaction, pleasure, and possibly profit of the member.

Young members should not select horses too large or headstrong for them to handle. Older and larger members may benefit most by selecting a yearling or 2-year-old horse and doing all the training. To select a horse that has been trained by a skilled or professional trainer defeats the purpose of the project. You should consult with the county agent about the age and type of horse.

On a farm or ranch, one or more brood mares for foal production may be advisable. Then the member may keep the foal until it is mature, and do all the steps in training. Registered mares are not required, but they may return a greater profit than grade mares.

Useful saddle horses may be found in all light breeds. Sometimes their ability depends more upon their care and training than upon their breeding.

\section{Care, Feeding, and Management}

Ownership and complete management characterizes all $4-\mathrm{H}$ projects. The $4-\mathrm{H}$ horse project recommends ownership of a horse or pony. It carries with it the responsibility for the health and well-being of the animal. An essential part of the club member's training is the early development of regular habits in feeding and caring for his mount.
Beginners, in particular, will usually be inexperienced in this. You can help the boys and girls get off to a good start by visiting them as soon as possible after the projects have begun. The following checklist covers some of the more important principles of good horse husbandry:

\section{Shelter and Premises}

Yes or No

If a stable is used, is it well lighted and ventilated and free from drafts?.......

Is stable large enough?

Do ceilings provide at least 8 feet of headroom?.

Does the horse have regular access to a corral or pasture with a good fence?. .

Are the stall, corral, and pasture free from loose or protruding boards, loose nails, tin cans, broken glass, wire, and other objects that can injure a horse?. .

\section{Feed and Water}

Yes or No

Is member feeding horse at regular times each day? . . . . . . . . . . . . . .

Does condition of animal indicate proper balance of feed?...........

Is grain free from mold and stored in a dry, clean place?................

Is the door to the feed-storage room securely fastened so that the horse can't break in and overeat?............

Is the hay of good quality and free from mold?.

Are feed boxes and hay rack set at convenient height for the horse?... . . . .

Does the horse readily clean up his grain within half an hour?..........

Does the horse have access to green grass during the season it is available?.

Have salt and minerals been provided? 


\section{Care of Horse}

Does condition of hair indicate that the horse has been groomed regularly?. .

Does the member have adequate groom equipment? Currycomb, coarse brush, fine brush, hoof hook, sponge and cloths?

Are first aid materials adequate for treating cuts and injuries, and kept at a convenient place?

Are the horse's feet cleaned out regularly?

If the horse is shod, are shoes in good condition and properly fitted? Are feet and pasterns in a healthy condition? Are walls of the hoof tough, free from cracks, and properly trimmed?.......

Is the horse free from lice, mange, ringworm, and other skin disorders?...

Does the horse show any signs of a heavy internal parasite infestation?....

Is there any indication of sore back or mouth?

Does the club member understand and practice warming up and cooling off the horse when it is ridden?

\section{Care of Riding Equipment}

Yes or No

Does the member have adequate material for cleaning and preserving equipment, such as saddle soap, neat's-foot oil, sponge, and cloths?.

Yes or No

$+\sqrt{-10}$

\section{Yes or No}
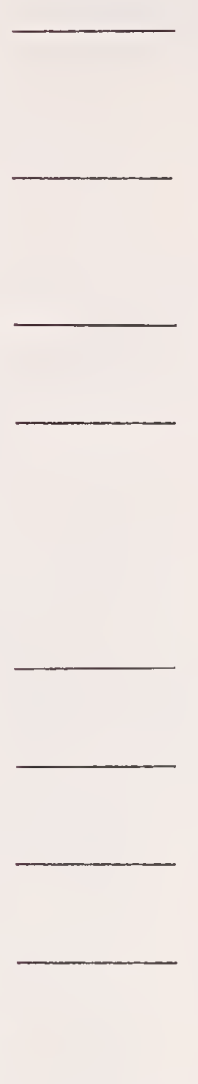

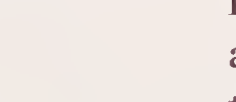

\section{Keeping Records}

Keeping accurate and complete records is important in the overall development of the 4-H Club member. Keeping records stimulates members to analyze results and strive for self-improvement, and it provides training that will help them later in life. Records 4-H members submit provide some of the information you need in selecting individuals to receive recognition and such awards as scholarships and educational trips.

Recordkeeping is easier for some than others. Guidance and encouragement from you and parents will help boys and girls take pride in keeping accurate and neat records that truly reflect their 4-H Club accomplishments. The county extension agents will acquaint you and club members with the types of records to be used for the 4-H horse project and will provide the necessary forms.

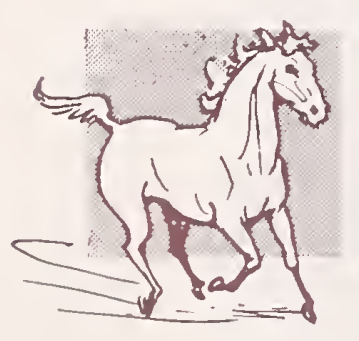

\section{TEACHING}

SUGGESTIONS
As a 4-H Club leader, you are also a teacher of boys and girls. The good teacher strives to hold the interest and cooperation of the pupils. Vary the way you present subjects as often as practical. $\Lambda$ wide variety is possible in teaching horse husbandry and horsemanship. Lectures, blackboard talks, movies, slides, demonstrations, judging contests, practice sessions, quiz contests, discussion periods, tours, and trail rides can all contribute to the learning process. Older and experienced 4-H Club members and other horsemen can help with the teaching. 


\section{Subject Matter Suggestions for Club Meetings}

Although a large part of instruction time will be spent outdoors with the horses, you may want to include subject matter as part of the program at regular 4-H Club meetings. Some of the subjects you can teach indoors are:

Breeds of horses and their uses

Parts of a horse

Principles of judging

Unsoundness, blemishes, and their locations

Riding-horse gaits (movie or blackboard talk)

Horse psychology

Horse health

Parts of riding horse equipment

Care of equipment

Making an adjustable rope halter for leading and showing

Feed and feeding

Safety precautions

First aid

Riding courtesies

Horse-show classifications and rules

How to train a horse.

\section{Demonstrations}

A demonstration is showing by doing. This method applies particularly in teaching horsemanship. Much of the subject matter in this program can be taught only by demonstrations followed by supervised practice sessions. The instructor who conducts his demonstrations skillfully quickly gains the confidence of his pupils.

As club members master each phase of their training, let them conduct demonstrations themselves. This way they develop poise, initiative, and the ability to impart knowledge to others. They can then help you train less experienced members. Some horse project subjects can be adapted to use as demonstrations in contests at county and state achievement meetings. Here are some suggestions for demonstrations:

Approaching, haltering, and leading a horse

Saddling, bridling, and adjustment of stirrups

Mounting and dismounting, proper seat and posture of rider

Use of aids in controlling the horsevoice, hands, legs, position of body

The different gaits and their influence on posture of rider

Changing leads

Teaching a colt to lead

Picking up and cleaning the horse's feet

Hoof trimming

Proper shoeing

The longe line and its use

Showing at the halter

Clipping and grooming

Braiding mane, foretop and tail

Care of equipment

Repair equipment, sewing and riveting

Judging horses

Determining age by the horse's teeth

Detecting unsoundness and blemishes

Teaching the horse to jump

Safe hauling, loading, and unloading horses

Feed mixing

Opening and closing gates from horseback

Ground tying

Useful knots and restraining devices

Hobbling and picketing horses 


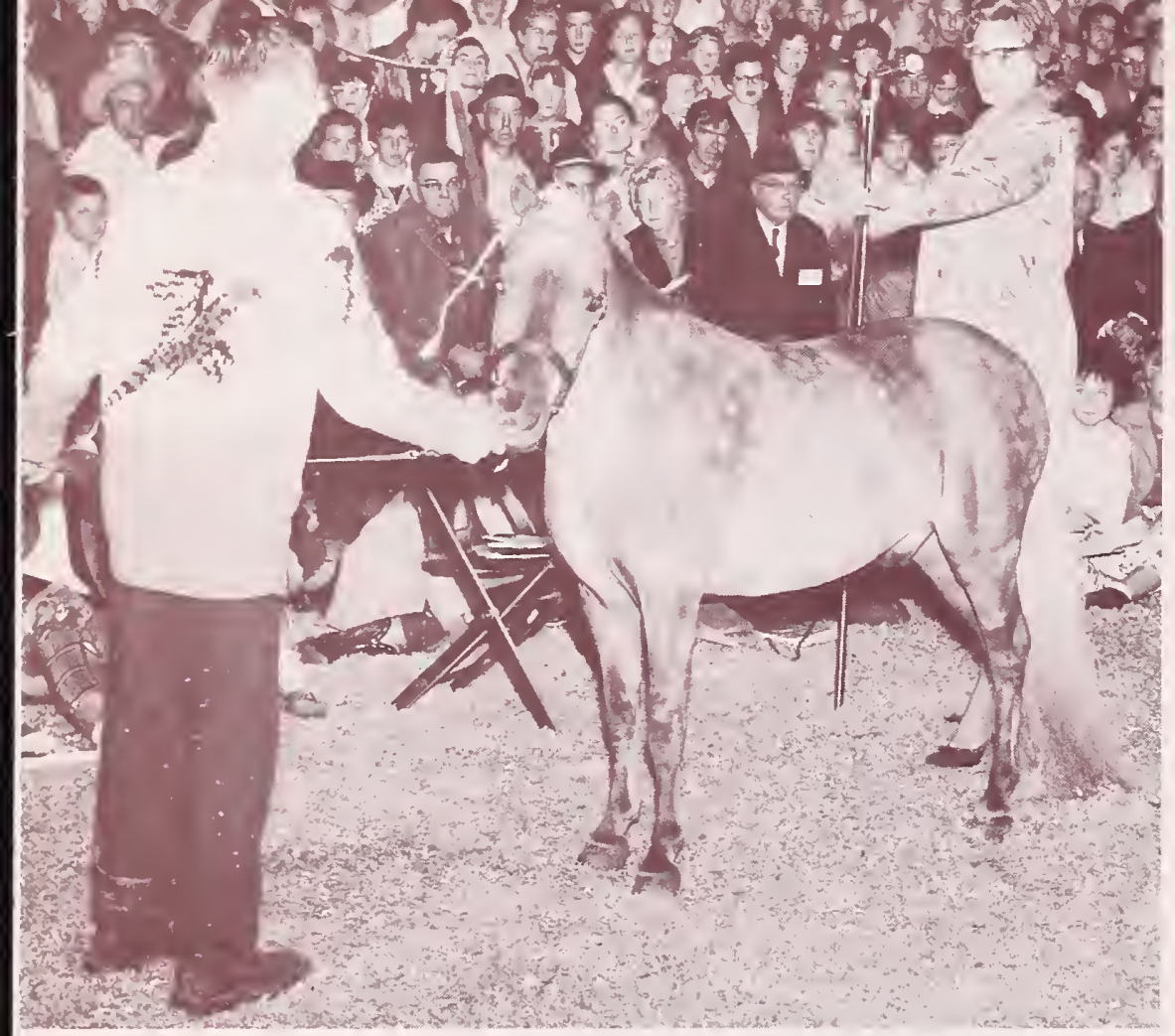

Judging school.

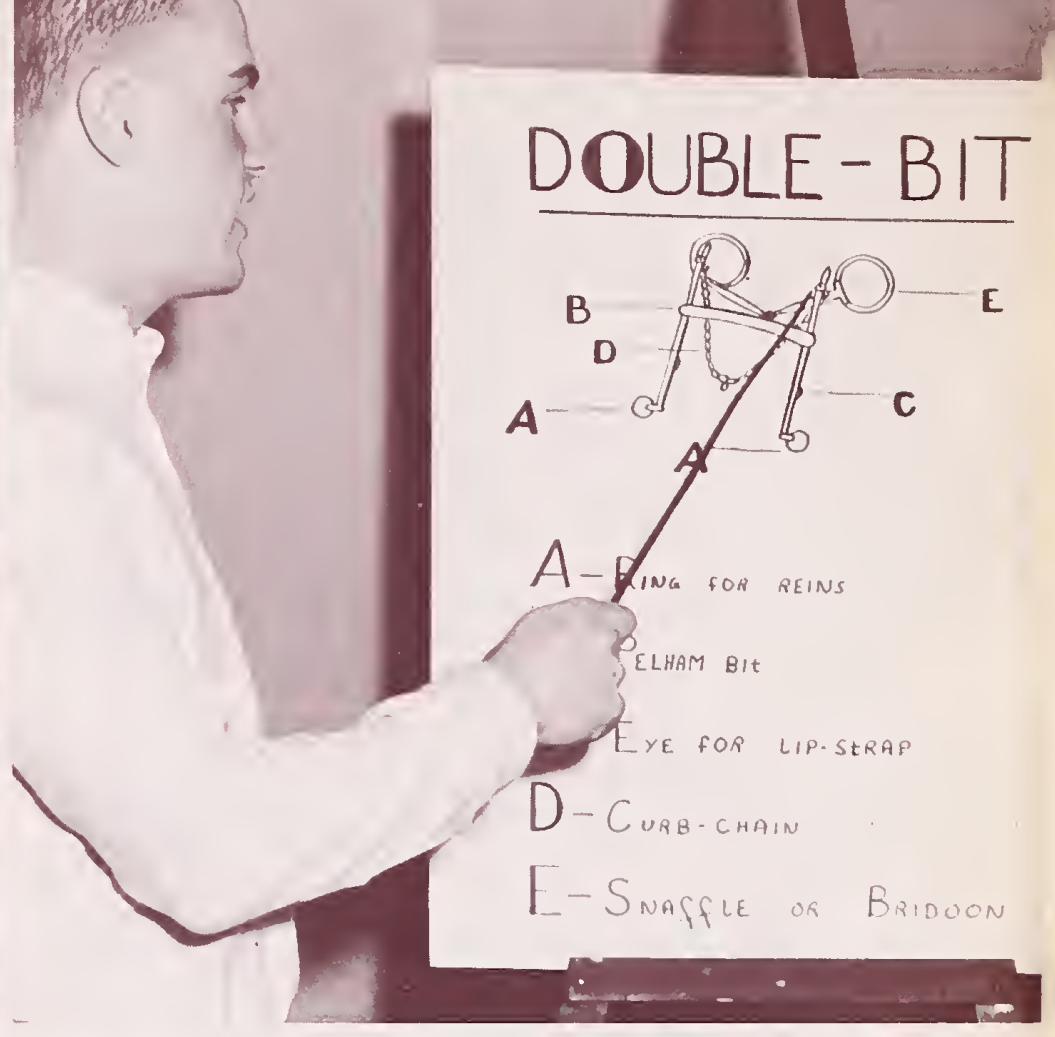

A lesson on equipment.

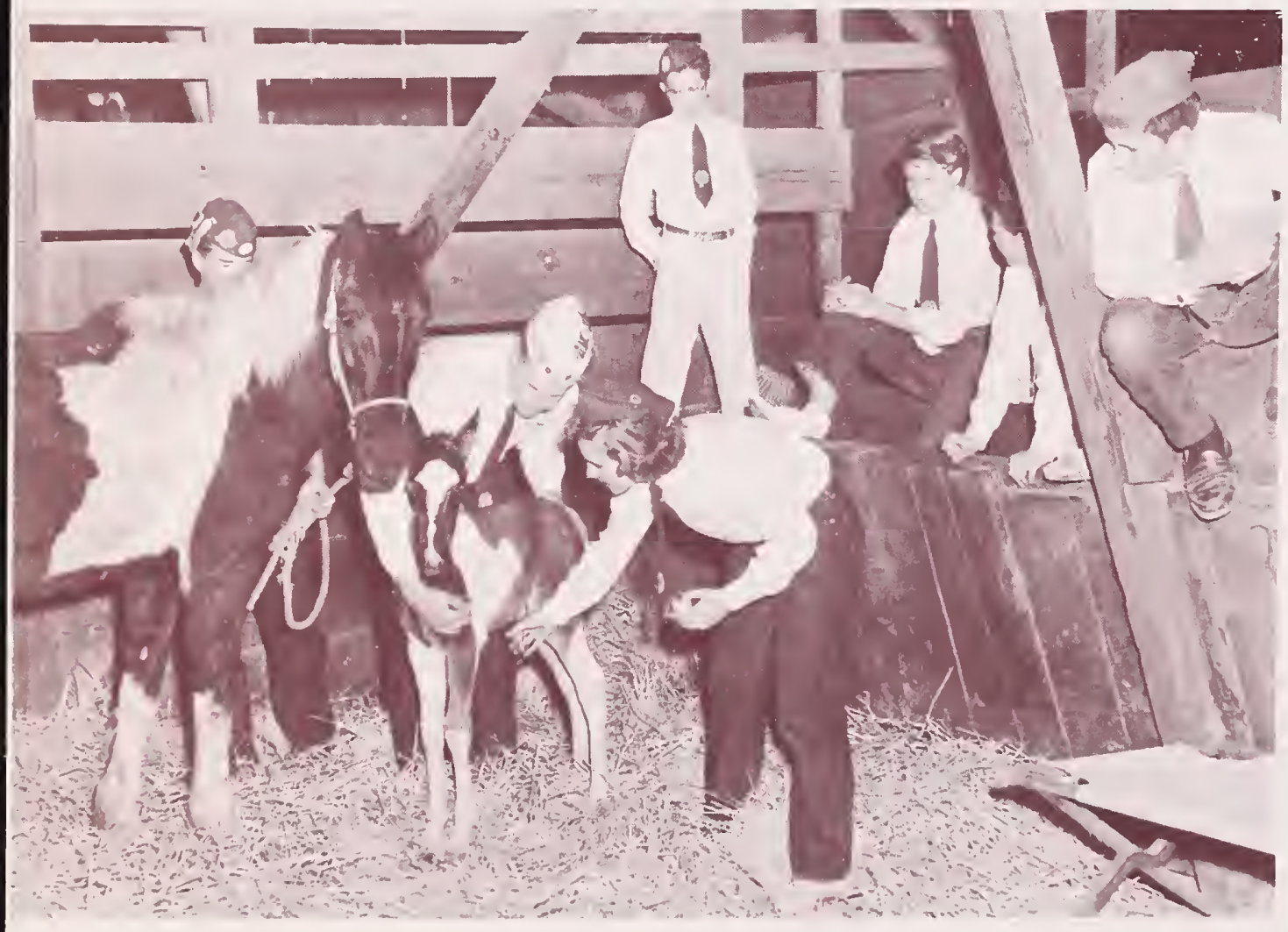

Junior leaders demonstrate care of mare and foal.
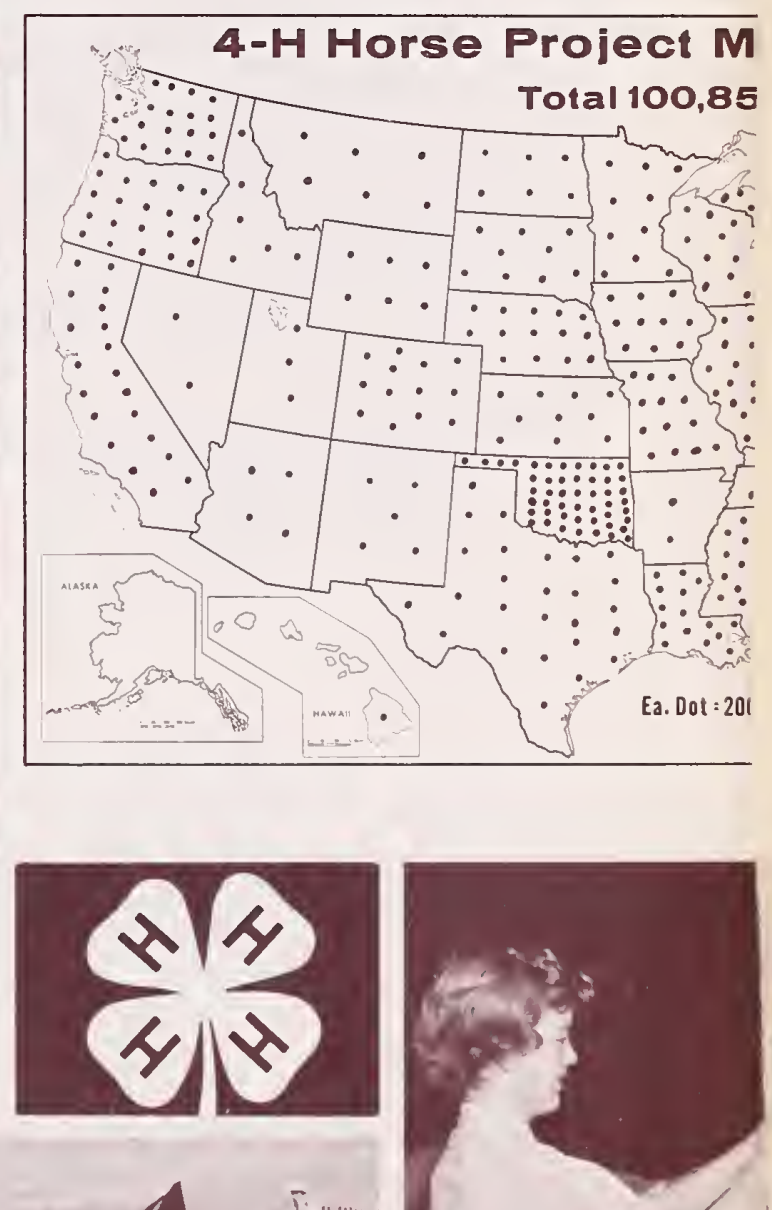

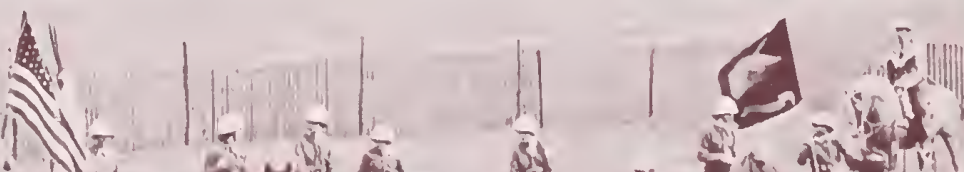

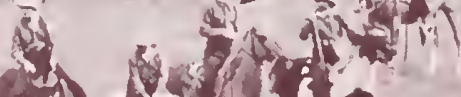

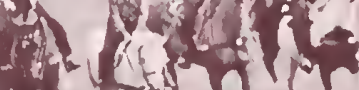

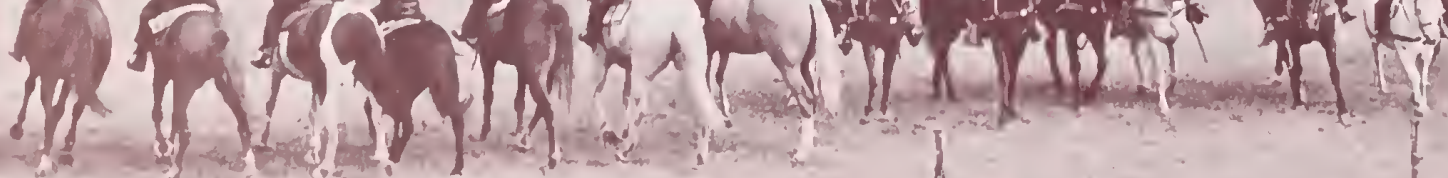

1

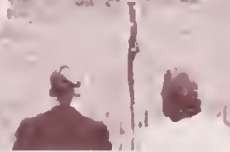

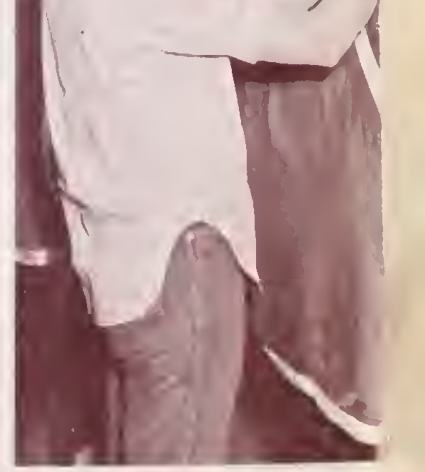

Preparir. 


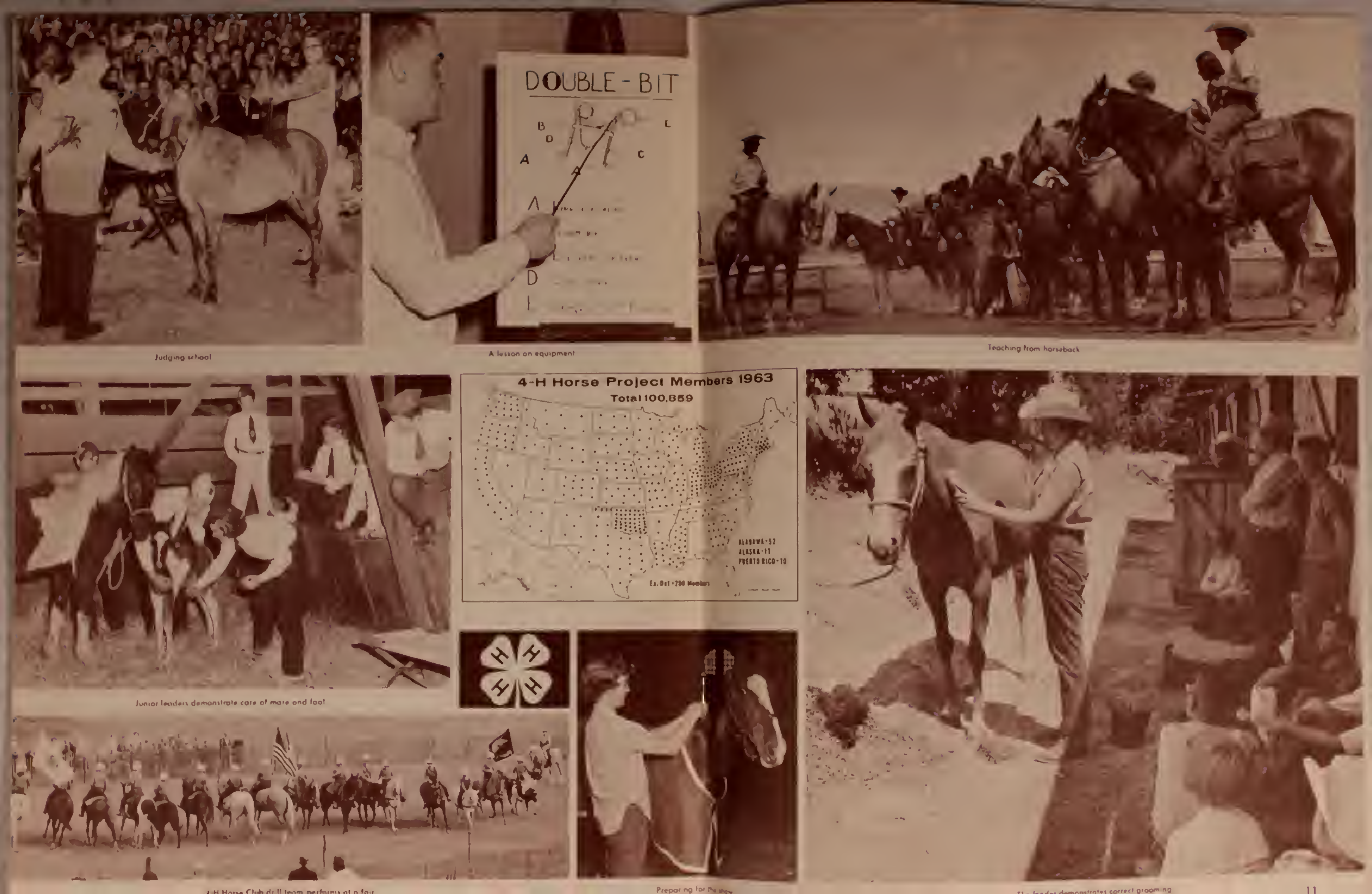




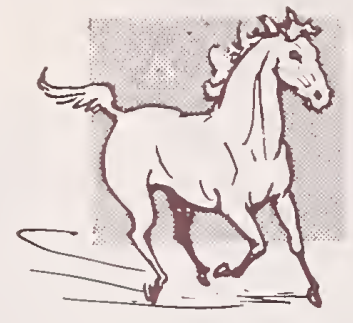

Showing his horse gives the member a chance to demonstrate what he has learned, and offers a good way for you to help him with further learning.

\section{Rules About Wording}

When the term "4-H" is used in connection with any horse show, the show management must have in writing the approval of the State Extension Director or a County Extension Agent.

Individuals or organizations sponsoring horse shows for their own gain should not use "4-H Horse Show". Use "Junior Horse Show sponsored by (name) 4-H Club" for a show under 4-H auspices and including other youth.

\section{Eligibility for Shows}

Suggested Rules for 4-H Light Horse Classes in a 4-H Achievement Show.

1. Both horse and rider must meet the requirements for the $4-\mathrm{H}$ horse project.

2. Stallions over one year of age are ineligible to compete. Foals may be shown in fitting and showmanship classes. Mare and Foal make a good class.

3. Each eligible horse must be listed as a 4-H horse project by May 1 of the current 4-H year.

4. No rider may show more than one horse in a class unless a separate entry fee has been paid.

5. Junior members must not be over 14 by January 1 of the current $4-\mathrm{H}$ year.
6. All senior members must have reached 14 years of age, and not exceeded 19 years of age by January 1 of the current $4-\mathrm{H}$ year.

\section{Organization}

Each show has divisions whereby all will have the opportunity to demonstrate their skill and workmanship.

1. Divisions suggested:
a. Fitting and showing
b. Judging by members
c. Halter classes
d. English riding
e. Western riding
f. Pony events
g. Games
h. Trail rides
i. Drills

2. Most shows have these basic divisions:
a. Fitting and showing (in halter)
b. Horsemanship
c. Obstacle event (trail or other activity to test skill and knowledge of mem- ber). Not so difficult but that a high percentage can complete the course.

3. These other divisions are optional:

a. Formal classes

Walk, trot, canter

Jumping

Working Stock

Other events
b. Games
c. Trail Rides
d. Drills 


\section{Some Horse Show Guidelines}

1. It is recommended that Junior and Senior events be held for "Fitting and Showing" and "Horsemanship" regardless of num. ber of exhibitors. The above classes may also be subdivided into English and Western.

2. Classes must be entered in advance of the event. No post entries accepted.

3. Classes to be cancelled must be done by the horse show management at the beginning of the show except when extreme danger exists. (Example-jumping in mud.)

4. A charge of 25 cents may be made for numerals (to be refunded when numerals are returned).

5. Each class shall be called at least two times, prior to the "last call." The gate then will be closed within two minutes of the last call.

6. Classes for horses are to be over 14 hands. Two pony divisions: under 12 hands, and $12.1-13.3$ hands.

7. Riders must keep horse under control at all times.

8. All horses entering the show grounds shall immediately enter the stabling or corral area. No horse is to be exercised except in the assigned area. No riding shall be per- mitted in the spectator area and no spectators in the exercise area.

9. Contestants at all times shall act as young ladies and gentlemen.

10. Unnecessary roughness or discourtesy will dismiss the rider from further competition in the events. Good sportsmanship shall prevail at all times-no abuse of animals or acting unmannerly. Steward is to be the judge here.

11. No jumping allowed by those mounted in a Western saddle.

12. Hard hats to be worn by riders in all Jumping or Hunt classes.

13. Suitable neat attire to be worn in all classes. Safety must be considered in all events. Sneakers and low shoes are not con. sidered suitable. Ladies' hair must not fall over their eyes.

14. Every show announcement is to carry a full description of what the class will be expected to do, and how it will be judged. (Example-back, jump 12 inches, figure 8 , dismount and mount.) Diagrams of special courses could also be illustrated.

15. Exhibitors must prepare their own animals for a fitting and showing class, without assistance except in holding, leading and loading. 


\title{
STANDARD SCORE CARDS
}

\section{for 4-H Classes}

These score cards show the points on which horse show events are judged. You might reproduce these for your club members to use in preparing to appear in horse shows.

\section{FITTING AND SHOWMANSHIP}

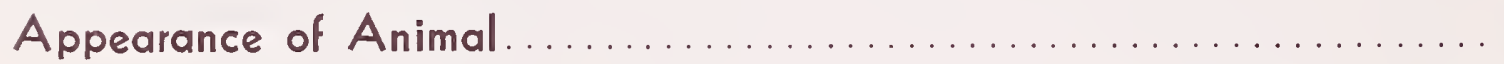 \\ A. Condition.................................... 15 \\ B. Grooming................................... 15
}

1. Coat clean and free of stains. Hair dressing and powder should be used sparingly.

2. Mane and tail free of tangles and clean.

3. Hoofs trimmed and shaped to enable animal to walk and stand naturally. If shod, shoes must fit and not show undue wear. Clinches should be smooth. Hoof dressing permitted.

C. Trimming and Braiding. ................................

1. Excess hair should be clipped or trimmed from fetlocks and around head. Horse may be totally clipped or not, as exhibitor wishes.

2. Braiding, if used, should be neat and suitable for the type of horse.

D. Tack-cleanliness and neatness..........................

Appearance of Exhibitor.................................... 10

Clothes and person-neat and clean. Suitable riding clothes preferred.

Showing Animal in the Ring

A. Leading

1. Enter leading animal at an alert walk and line up in the center of the ring as designated by the ringmaster. Walk on animal's left side holding reins or lead strap (if weanling) in right hand close to bit or halter. The remaining portion of reins or strap is held in the left hand. Animal should lead readily at walk and trot. 
2. Only weanlings should be shown in halter. Older horses are to be shown in a bridle. The bridle should fit properly and be clean.

3. When making a turn, the horse should be turned to the right, exhibitor walking around the horse.

4. Lead horse at a brisk walk or trot as judge directs, with animal's head carried at a height appropriate to the type or use of horse.

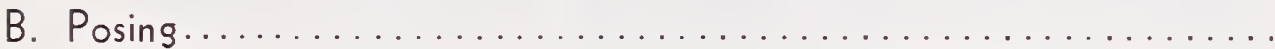

1. When posing your horse, stand toward the front and facing the horse, but always in a position where you can keep your eye on the judge.

2. Pose animal with feet placed squarely and according to its type and use.

3. Face animal upgrade, if possible, with its front feet on a light incline.

4. Do not crowd the exhibitor next to you when leading into a side-byside position. Do not crowd exhibitor in front when lined up head to tail.

5. Animal should be led forward when judge requests that its position in line be changed, then led around the end of the line to the position indicated by the judge. Do not lead animal between judge and the animal he is observing.

6. Do most of the showing with reins or lead strap. Never kick horse's leg into position. Proper use of hands, voice or whip accepted.

7. When judge is observing other animals, let yours stand if posed reasonably well.

8. Be natural. Overshowing, undue fussing and maneuvering are objectionable.

C. Show Animal to Best Advantage ..........................

Quickly recognize the conformation fault of animal you are leading and show it to overcome this fault. Exhibitor may be asked to exchange horses with another exhibitor.

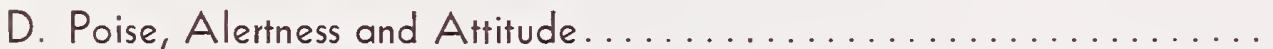

1. Keep an eye on your animal and be aware of the position of the judge at all times. Do not be distracted by persons and things outside the ring.

2. Show animal at all times, not yourself.

3. Respond rapidly to requests from the judge and officials.

4. Be courteous and sportsmanlike at all times.

5. Keep showing until the entire class has been placed and the judge has given his reasons.

Total 


\section{WESTERN HORSEMANSHIP \\ (Rider is being judged)}

Hands-Solthands, one hand on reins, palms up above and just forward of saddle horn. Do not change hands. Keep hand around the reins. Neck rein the horse with hand reining straight across on horizontal plane, with a loose rein. Relax the arm to place free hand on thigh. Hands do not touch saddle or horse......

Seat-Establish and maintain a correct, secure seat, heels down ............. 15

Appointments of Rider-Neat and clean, boots preferred. Western apparel..... 5

Suitability-Rider fits horse; spirit of horse equal to rider's ability .............

Appointments of Horse-Western tack; saddle should fit the rider. Half breed, spade or curb bit may be used-wire, chain or other metal or rawhide device is not permissible as part of the leather chinstrap tiedowns. Running martingales and draw-reins not permitted. Spurs are optional. Bosals or cavesson-type

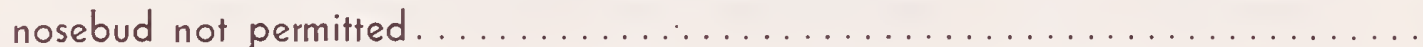

Performance-Unsoundness of horse shall not penalize a rider unless it impairs the required performance. Walk, jog, lope, and reverse, pass on the inside, walk before change of gaits, neck rein. Back horse two lengths; complete a dismount and mount. Start on either lead; change leads on straightaway. Be able to answer pertinent questions the judge may ask. Results as shown by performance of the horse are not to be considered more important than the method used in

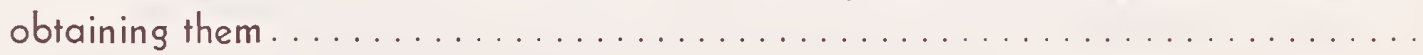

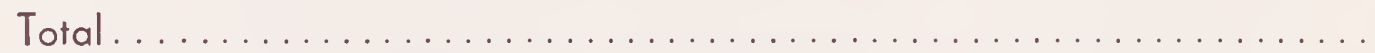

\section{WESTERN PLEASURE}

Performance and Manners of Horse-Walk, jog, lope, pass on the inside, reverse, back two lengths, dismount, mount (horse should stand). . . . . . . . . . . . .

Appointments - Standard western bit. Tiedowns are not permitted. Spurs are optional. Wire, chain, metal or rawhide device is not permitted as part of the leather chinstrap. A bosal should allow room for three fingers. A curb strap should be loose enough to allow two fingers to be inserted under it ............

Conformation

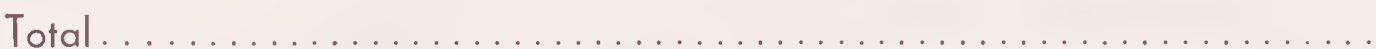

\section{WORKING STOCK HORSE}

Rein-Only one hand on reins; must be around reins. Hands must not be changed. Hands must be clear of horse and saddle while horse is working. A light hand is very important. . 
Manners-Fault horse for switching tail, nervous throwing of head, halting or hesitation while being exhibited, particularly when being run out, indicating anticipation of being set up. Exaggerated opening of mouth, hard mouth, tugging on bridle

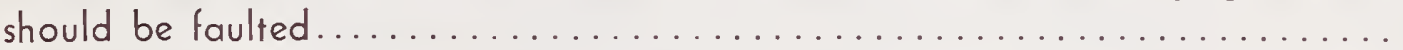

Appointments-Exhibited with stock saddle. Martingale choke rope or tiedown not permitted. Chain, wire, metal or rawhide device is not permitted as part of the leather chinstrap. Spurs are optional. Suggest boots and western

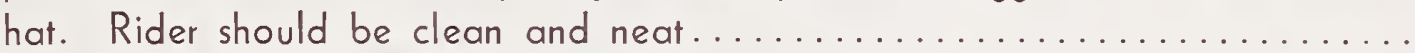

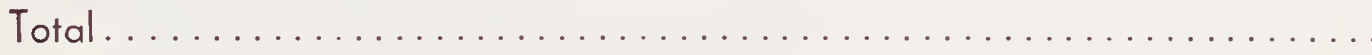

\section{ENGLISH HORSEMANSHIP (Rider is being judged)}

Position-Establish and maintain a secure seat. Soft hands holding two reins in each hand. Snaffle rein outside the little finger. Hands in line with bit and elbow. Feet resting on ball of foot, in the stirrup, heels down. No noticeqble swaying

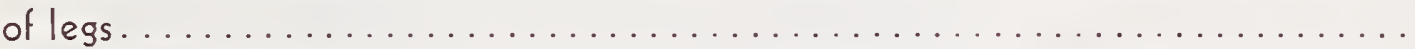

Performances-Walk, trot, canter both ways of ring, may be asked to back, pose, dismount and mount. Seniors may be asked for individual workout including the figure 8. Posting on the correct diagonal, showing in correct lead at the canter, changing of lead or diagonals may be required. Voice, hands and legs important in the use of aids for desired gait or maneuver. .

Attire and Equipment-English or McClellan saddle, Pelham or Weymouth bridle. No martingale or tiedowns allowed. Curb strap adjusted for two fingers, spurs

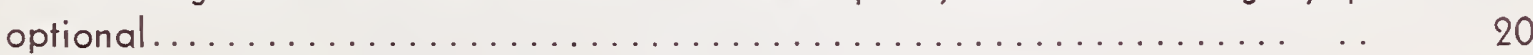

Suitability -Rider to fit horse. Manners equal to rider's ability............... 10

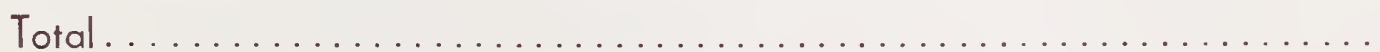

\section{ENGLISH PLEASURE}

Performance and Manners of Horse-Walk, trot, canter both ways of ring, back, dismount and mount. Horse to work on loose rein. Rider not to lose contact with horse's mouth. May be asked to trot on or gallop. No racing or overshowing to be allowed. No tossing of head, no anticipated stops to be shown

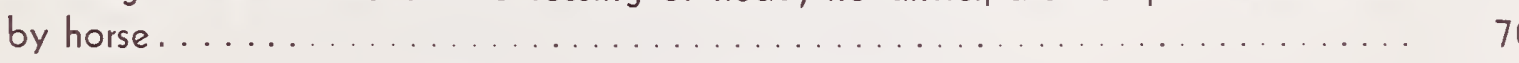

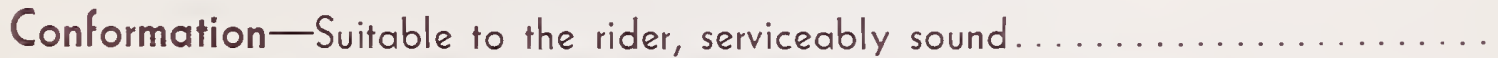

Appointments-English or McClellan saddle. Open stirrup, Pelham or Weymouth bridles. No martingales, tiedowns allowed. Use a curb strap, not a chain, allow two fingers. . . . . . . . . . . . . . . . . . . . . . . . . . .

Total 
Performance-Walk, trot or jog, canter or lope both ways of ring. A series of obstacles may be set up for individual testing. (Dry bridge, open and close gates while mounted, pick up and discharge mail, back through rails, ride over simulated corrugated road, low jump not over 12 inches, others.) . . . . . . . . . . . . 70

Appointments - Complete and neat for style of riding ................. 20

Conformation and Condition-Suitable for rider..................... 10

Total. ......................................... 100

\section{CLOTHING AND EQUIPMENT SUGGESTIONS}

Western Riders

Western pants (not blue denim)

Boots

Shirt

Tie

Western saddle

Rope for stock saddle (optional)

Hat

Western bridle without chain
English Saddle Seat

Saddle seat pants

Jodphur shoes

White shirt

Tie or collar

Coats

Saddle seat saddle

4-line bridle

Derby

\author{
English Hunter Seat \\ Riding breeches \\ Hunter boots \\ White shirt \\ Tie or stock \\ Coats \\ Hunter hats \\ Hunter seat saddle \\ 2 or 4-line bridle
}




\section{SAFETY PRECAUTIONS}

Careful attention to simple safety rules in handling horses prevents serious mishaps. You must know safe riding when you are training riders. Here are basic rules of safety you need to stress constantly so that members will develop the habit of practicing safety at all times.

1. Never approach a horse directly from the rear. Even in single stalls it is possible to approach from an oblique angle at the rear.

2. Always speak to a horse before approaching or touching him. Most horses are likely to jump and may kick when startled.

3. If the horse hangs back on the end of the rope, lead him a few steps forward before touching him with your hand.

4. Keep your head in the clear when bridling the horse. He may throw his head or strike to avoid the bridle. Avoid bridling a nervous animal in close quarters.

5. Walk beside the horse when leading, not ahead or behind him. Always turn the horse to the right, and walk around him.

6. Use a long lead strap and both hands when leading. If the horse rears up, release hand nearest the halter so you can stay on the ground.

7. The horse is stronger than you, so don't try to outpull him. He will usually respond to a quick snap on the lead strap or rope.

8. Never wrap lead strap, halter shank, or reins around your hand, wrist, or body.

9. Keep bridle reins, stirrup leathers, and cinch straps in the best possible condition, as your safety depends on these straps. Replace any strap when it begins to show signs of wear.

10. Stand with your feet well back in the clear and reach forward when saddling the mount.

11. Never mount the horse in a small barn, near fences, trees, or over-hanging projections. Side-stepping mounts have injured riders who failed to take these precautions.

12. Adjust the saddle carefully and the cinch tight enough so it will not turn when you mount. Lead the horse a few steps before mounting.

13. Soon after starting the ride, dismount and again tighten the saddle girth. Horses often swell up when first saddled, and failure to tighten girths later can result in serious accidents.

14. If your horse is frightened by an obstacle, dismount and lead him by it.

15. Keep your horse under control and maintain a secure seat at all times. Horses are easily frightened by unusual objects and noises. Anticipate these and steady your horse.

16. When a horse is frightened and attempts to run, turn him in a circle and tighten the circle until he stops.

17. When riding in groups, do not ride too close to the horse in front of you, and be alert for overhead tree branches.

18. Hold your mount to a walk when going up or down hills.

19. Reduce speed when riding rough ground or in sand, mud, ice or snow, when there is danger of the mount's falling or slipping.

20. Avoid paved roads. Slow your mount to a walk when crossing such roads. If he is a spirited or young horse, dismount and lead him across.

21. Know your horse, his temperament and reactions. Control your temper at all times, but let him know that you are his firm and kind master.

22. Ask permission when leading through a group of people.

23. On long rides, dismount and lead for five minutes each hour. 


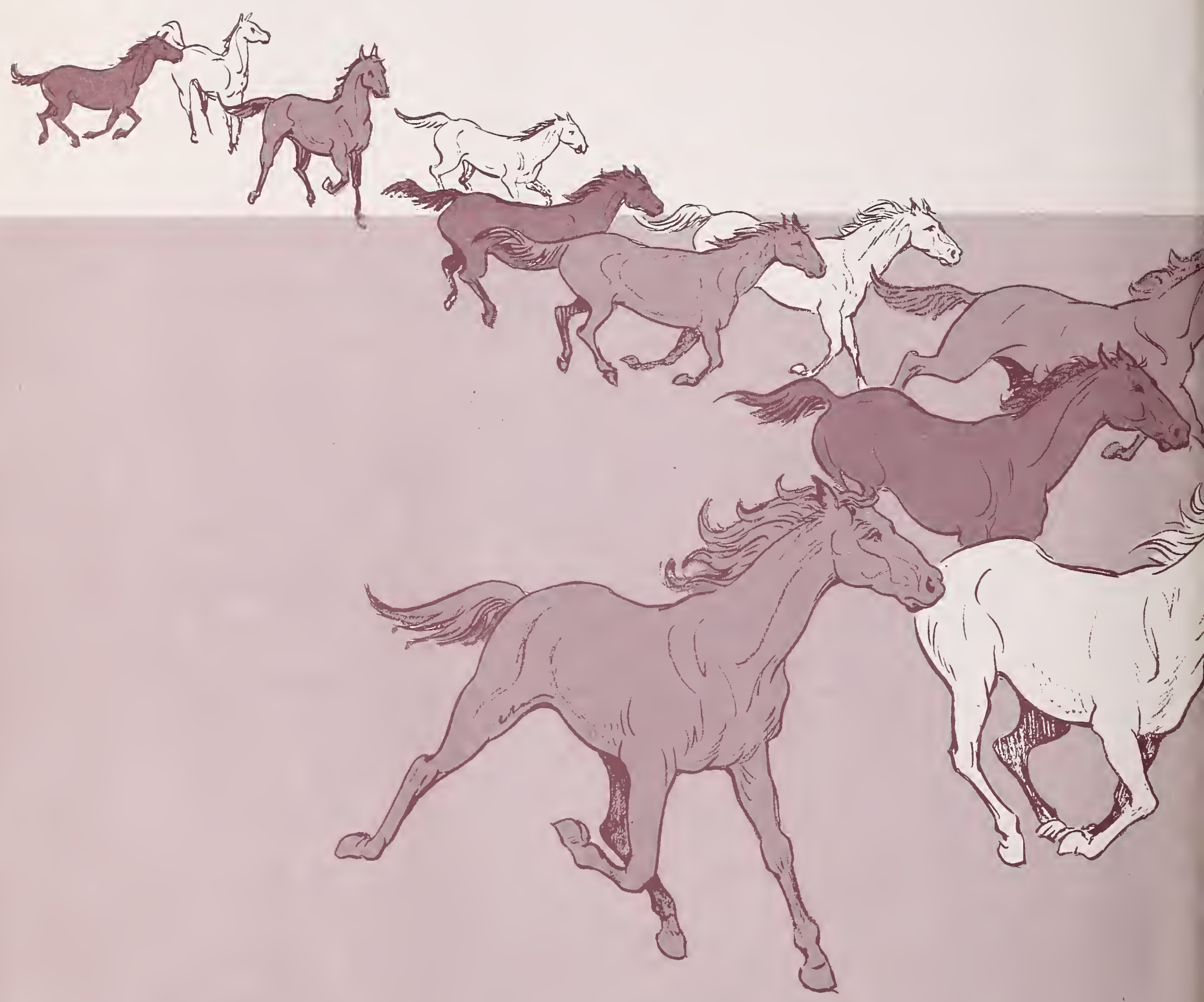

